\title{
THE LONG TERM EFFECTS OF THE DIVORCE REVOLUTION: HEALTH, WEALTH, AND LABOR SUPPLY
}

\author{
Kristin Mammen \\ CRR WP 2008-22 \\ Released: November 2008 \\ Date Submitted: October 2008 \\ Center for Retirement Research at Boston College \\ Hovey House \\ 140 Commonwealth Avenue \\ Chestnut Hill, MA 02467 \\ Tel: 617-552-1762 Fax: 617-552-0191
}

The research reported herein was pursuant to a grant from the U.S. Social Security Administration (SSA) funded as part of the Retirement Research Consortium (RRC). The findings and conclusions expressed are solely those of the authors and do not represent the views of SSA, any agency of the Federal Government, the RRC or Boston College.

(C) 2008, by Kristen Mammen All rights reserved. Short sections of text, not to exceed two paragraphs, may be quoted without explicit permission provided that full credit, including (C) notice, is given to the source. 


\section{Abstract}

The effects of divorce on individuals and on society as a whole has been widely debated in public discussion of American life.1 The dialogue was sparked by the dramatic rise in the number of U.S. divorces which began in the 1960s: Figure 1 illustrates that the divorce rate doubled from 10.6 to 20.3 divorces per 1,000 married women between 1965 and 1975, and continued to rise until 1981.2 Scholars have also debated the implications of the 'Divorce Revolution' of this time period: the liberalization of divorce laws in a large number of states to a unilateral regime, which made divorce easier by requiring the consent of only one spouse to dissolve a marriage (e.g., Friedberg 1998, Weitzman 1995).3 Some policymakers, 14 social scientists, and advocacy groups have argued that this sweeping policy change was an important factor in a general decline of the American family (e.g., Kirkwood 1996, Parkman 1993). Gruber (2004) found that children exposed to the unilateral divorce laws have poorer outcomes in young adulthood. On the other hand, the easing of divorce laws made it easier for people to leave toxic marriages, and arguably increased the bargaining power of abused partners within marriages; Stevenson and Wolfers (2006) find large declines in domestic violence in states that adopted unilateral divorce. This paper contributes to the evaluation of the change in divorce laws by examining a less studied area: the long term effects of this policy change on the well-being of men and women who were young adults when the laws were changing. This paper will examine laterlife measures including labor force status, earnings, wealth, and physical and mental health for these cohorts. This long term evaluation is important because this generation of Americans is now approaching and just beginning the retirement years. The aging of the population and the demands it will place on social service programs and future generations of workers is already an important topic for social scientists and policy makers (He et al. 2005). Understanding whether the wellbeing of cohorts affected by the divorce law changes differs from earlier retirees' will aid in this planning. 


\section{Introduction}

The effects of divorce on individuals and on society as a whole has been widely debated in public discussion of American life. ${ }^{1}$ The dialogue was sparked by the dramatic rise in the number of U.S. divorces which began in the 1960s: Figure 1 illustrates that the divorce rate doubled from 10.6 to 20.3 divorces per 1,000 married women between 1965 and 1975, and continued to rise until 1981. ${ }^{2}$ Scholars have also debated the implications of the 'Divorce Revolution' of this time period: the liberalization of divorce laws in a large number of states to a unilateral regime, which made divorce easier by requiring the consent of only one spouse to dissolve a marriage (e.g., Friedberg 1998, Weitzman 1995). ${ }^{3}$ Some policymakers, social scientists, and advocacy groups have argued that this sweeping policy change was an important factor in a general decline of the American family (e.g., Kirkwood 1996, Parkman 1993). Gruber (2004) found that children exposed to the unilateral divorce laws have poorer outcomes in young adulthood. On the other hand, the easing of divorce laws made it easier for people to leave toxic marriages, and arguably increased the bargaining power of abused partners within marriages; Stevenson and Wolfers (2006) find large declines in domestic violence in states that adopted unilateral divorce. This paper contributes to the evaluation of the change in divorce laws by examining a less studied area: the long term effects of this policy change on the well-being of men and women who were young adults when the laws were changing. This paper will examine later-life measures including labor force status, earnings, wealth, and physical and mental health for these cohorts. This long term evaluation is important because this generation of Americans is now approaching and just beginning the retirement years. The aging of the population and the demands it will place on social service programs and future generations of workers is already an important topic for social scientists and policy makers (He et al. 2005). Understanding whether the wellbeing of cohorts affected by the divorce law changes differs from earlier retirees' will aid in this planning.

\footnotetext{
${ }^{1}$ e.g. Council on Families in America 1995, Hetherington 2002, Pollitt 1997, Whitehead 1993, 1997.

2 The spike around 1945 reflect the increase in divorce typical in the aftermath of every recent major war (Cherlin 1992).

${ }^{3}$ Weitzman termed the divorce law changes the divorce revolution. The phrase has also been used to describe the precipitous rise in the divorce rate, and a wider social phenomenon, the onset of a "divorce culture" replacing the older "marriage culture" (Council on Families in America 1995, Whitehead 1997).
} 


\section{The Effects of Divorce Law Liberalization}

The most obvious channel through which a change in divorce law could affect an individual's later life outcomes is if the law change triggered the disruption of his particular marriage. The economic circumstances of women and their children, in particular, decline at the time of divorce (e.g. Page and Stevens 2004), and being divorced is associated with poorer health and financial status for older Americans (Pienta et al. 2000, Social Security Administration 2006, p. 147-8). But changes in divorce laws potentially change individuals' decision-making in a host of other areas that could affect their long term prospects, even if they themselves do not divorce.

The question of whether divorce law liberalization had a causal effect on the divorce rate increase, which speaks to the importance of the first channel, has generated much discussion among economists, sociologists, and legal scholars. ${ }^{4}$ Two types of law changes constituted divorce law reform. The change from "fault" to "no-fault " substituted "irreconcilable differences" as a legal basis for divorce in place of grounds such as adultery or cruelty, which previously required formal proof and often resulted in perjury and collusion between spouses in order to obtain a legal divorce (Riley 1991, Weitzman 1985). The second, often overlapping, change was from the requirement that both spouses agree to divorce (mutual-consent) to only one (unilateral). Legal scholars have argued that the law changes were carried out "with little visibility or prominence," (Jacob 1988 p. 15), by lawmakers and legal experts who wished to remove the adversarial elements from the proceedings and who felt the dignity of the law suffered from the machinations of judges, lawyers, husbands and wives to prove the often fabricated grounds (e.g., Freed and Foster 1979, Riley 1991, Sepler 1981). A number of scholars have therefore argued that the law changes were exogenous to the lives of those affected (e.g., Friedberg 1998, Gruber 2004, Wolfers 2006).

Economists have focused on the transition from mutual-consent to unilateral laws in assessing causation between divorce law reform and divorce rates, because of the intriguing implications of the Coase theorem for this relationship (Becker, Landes, and Michael 1977, Coase 1960). Assuming spouses can bargain costlessly, only efficient divorces will occur, those for which the total value of the marriage is less than the sum of

${ }^{4}$ See Glenn 1997, Nakonezny et al. 1995, Rodgers et al. 1999; Brinig and Buckley 1998, Ellman 2000, and Ellman and Lohr 1998. 
the spouses' opportunities outside of marriage. The change to a unilateral divorce law changes assigned property rights - who has the right to divorce; if spouses can easily bargain, this will not change the incidence of divorce but may change the compensation schemes which ensure these efficient outcomes. The schemes include how spouses divide their time between market work, home production, and leisure. Peters (1986) considered this model in depth and found that the divorce law regime was unrelated to divorce rates but that the unilateral regime was associated with lower settlements for women, a result consistent with the idea that husbands who wished to leave marriages could decrease compensation to their wives under unilateral regimes relative to mutual consent.

Peters and other scholars have explored theoretical conditions under which the Coase theorem would not apply and divorce law reform would change divorce rates (Chiappori, Iyigun, and Weiss 2007, Mechoulan 2005, 2006, Rasul 2006). Debate continues on the empirical side as well. Allen (1992) disputed Peters' results, finding that the divorce law change did increase divorce rates. Friedberg (1998) using longitudinal data found strong effects of divorce law reform, but Wolfers (2006) argues that the effect was transitory. In this paper I find that the divorce law changes are associated with an increased likelihood of being divorced or ever-divorced, suggesting that some of the effects on later life outcomes potentially work through the experience of having been divorced.

But even if a particular individual did not divorce as a result of the divorce law reform, an increase in the perceived risk of divorce potentially changed her behavior even if the effect on divorce rates was not long term. A reduction in expected marriage duration reduces the value of specialization and marriage specific investments. This may be particularly important for women because their human capital acquisition is traditionally more focused on marriage-specific home production skills whose value may be dissipated when a marriage dissolves, whereas the value of market skills, held by men in greater proportion, may be more transferable to the single state. The reassignment of the right to divorce also shifts bargaining power from the spouse who most values the marriage to the spouse most interested in divorce. Divorce law reform may then precipitate behavioral changes, with weaker spouses accommodating the stronger spouse's preferences or attempting to maintain bargaining power by improving their outside 
options - through increasing market work, for example. Attachment to marriage will vary over individuals, but it is likely that the spouse with fewer options is often the wife, since women's economic circumstances decline on average after divorce (Page and Stevens 2004) and they are likely to bear more of the subsequent childrearing costs .

The response of women's labor supply to divorce risk and to changes in divorce law have already received attention in the literature. Johnson and Skinner (1986) find that married women increase their labor supply prior to a divorce, and argue that the increase results from the anticipation of divorce, rather than precipitating the divorce. Papps (2006) finds similar results. Cross-sectional results often show a positive association between divorce law reform and women's labor supply, while longitudinal results are more mixed. ${ }^{5}$ Genadek, Stock and Stoddard (2007) argue that differing results could be explained by heterogeneous impacts of divorce law changes, if women have different costs of bargaining and divorce. They find that divorce law reform increases the labor supply of married mothers, especially those with young children, relative to other women. If young women made different labor supply choices as a result of a changing divorce-law environment, it is quite likely that their career paths were affected throughout their working lives. The long-term lens of this paper allows an evaluation of the cumulative magnitude of these impacts as these affected cohorts age.

\section{Data}

The Health and Retirement Study (HRS) was designed to study the well-being and decision making of older Americans and is uniquely suited to the current investigation. The data contain detailed labor supply, health and economic status measures. The respondents were aged 17 and up in 1970, a time of life when the divorce-law regime was most likely to have an effect on their decision making about marriage and divorce. The HRS also has the geographic information necessary to match respondents to the divorce law regimes that prevailed in their young adulthood. The survey collects state of birth and also asks respondents which state they lived in while they were in high school (or elementary school or at age 10 , if they did not complete high school). ${ }^{6}$ No other data

\footnotetext{
${ }^{5}$ Chiappori, Fortin, and Lacroix 1992, Parkman 1992, Peters, 1986, 1992; Gray 1986 and Stevenson (no date).

${ }^{6}$ Although where a respondent lived in high school is not a perfect measure of which state's laws he or she was subject to when making decisions about marriage and divorce, it is the best measure available. When studying the long term effects of state-level policies, researchers often only have state of birth available as
} 
set combines large sample size, comprehensive outcome measures for older Americans, and the necessary geographic information.

The HRS is a longitudinal survey which began in 1992 and has continued usually biannually since then. The initial survey targeted those born 1931-41, known as the HRS initial cohort, although spouses of different ages were also interviewed. Older and younger cohorts have since been added so that the population of inference for the pooled sample is all persons born before 1953 and still living at their initial survey. The Asset and Health Dynamics among the Oldest Old cohort (AHEAD) born 1923 and earlier, was first interviewed in 1993; in 1998, the Children of Depression (CODA) and War Baby (WB) cohorts, born 1924-30 and 1942-47 were added; and the Early Baby Boomers (EBB), born 1948-1953, were added in 2004 (St. Clair et al., 2006). There are 30,207 respondents when the cohorts are pooled; for each respondent I include the first observation which has a positive weight. ${ }^{7}$ I exclude 1,634 respondents who do not have a positive weight for any observation, as well as 58 people born after 1953 and one with missing birth year information. Also dropped are 628 respondents who report living in another country or in a U.S. territory as a youth, and 2,744 with missing information for that question. I restrict the sample to those who are age 51 to 90, excluding 207 people, leaving a sample of 10,570 men and 13,365 women.

Respondents' reports of the state they lived in as a youth are used to match them with that state's divorce law regime over time. The year of the change to a unilateral law for each state is shown in Table 1; this information was compiled by Gruber (2004), and is an update of documentation in Friedberg (1998). The results in this paper are robust to using Friedberg's classification of the timing of the law changes, as well as using the state of birth rather than the state lived in as a youth.

Summary statistics for the sample stratified by gender are presented in Table 2 .

the geographic measure linking individuals to earlier policy changes (e.g., Gruber 2004, Lleras-Muney 2005). The Panel Study of Income Dynamics and National Longitudinal Studies of Older Men and Mature Women have state of residence at the time of the interviews (which began in 1967 and 1968), but their sample sizes are much smaller than the HRS. The NLS cohorts are also quite a bit older than the HRS cohorts, making it likely that the divorce law changes did not affect them as strongly.

${ }^{7}$ An alternative would be to include all weighted observations from different waves for each individual, correcting the standard errors for correlation between observations on the same person, potentially increasing the precision of the estimates. However, adding observations for the same person does not add variation to the right hand side variable of interest, which is exposure to a liberal divorce law in the person's youth. 
Reflecting women's higher life expectancies (He et al. 2005), the women in the sample are older on average and more likely to be widowed than the men. Because they are less likely to survive their spouse into widowerhood, men are more likely to be married. Another contributor to the greater proportion of men who are married is that men are more likely to remarry, and remarry at shorter intervals, following divorce or death of a spouse (e.g., Wilson and Clarke 1992). Their higher remarriage rates can be seen also in that men are more likely to be ever-divorced (reporting at least one divorce, regardless of current marital status) but less likely to be currently divorced than are women.

\section{Results for Divorce}

To examine whether the liberalization of divorce laws increased the occurrence of divorce for those in the HRS sample exposed to the laws, I estimate a linear probability model separately for men and women:

$$
D_{i}=\alpha+\sum_{k} \beta_{k} \cdot \operatorname{EXP}_{i k}+X_{i}^{\prime} \delta+\sum_{s} \eta_{s} \cdot \text { state }_{i s}+\varepsilon_{i}
$$

where $\mathrm{D}_{i}$ is an indicator for the individual's marital status in the survey year. Two dependent variables are used in separate specifications: an indicator for being currently divorced and an indicator for being ever divorced, since both have been shown to have implications for well-being in later life (Holden and Kuo 1996, McNamara et al. 2003). The independent variables of interest are the $E X P_{i k}$ which measure respondents' exposure to divorce law liberalization. They comprise a set of indicator variables, the $k$ th of which is equal to one if the person experienced a law change in her state while in age category $k$, while the remaining $k-1$ indicators are equal to zero. The categories are never-exposed, denoting respondents who lived as youths in states which never changed their laws (Column 1 of Table 1), and exposed at ages 0-15, 16-25, 26-35, with the omitted category being exposed at ages 36 and over. "Exposure" captures the key transition from mutual consent to a unilateral regime, so a person who was a child when the law changed has a value of one for "exposed at age $0-15$ ", and values of zero for exposure at older ages. ${ }^{8}$ This specification is chosen for two reasons. The probability of divorce decreases with a person's age and with the duration of a marriage (e.g., Clarke 1995), so the shock of a divorce law change may have had different effects on couples in more or less stable

\footnotetext{
${ }^{8}$ Specifically, the individual exposed as a child has a one for exposed at ages $0-15$, and zeroes for neverexposed, exposed at ages 16-25, exposed at ages 26-35, and exposed at ages 35 or older.
} 
periods in the marriage cycle. Secondly, the impact of a law change could depend in other ways on the life stage of the individual when the law change occurs: younger people may have greater scope than older people to change their education paths, career investments, and other life choices when they see the terms of the marriage contract changing around them. $\boldsymbol{X}_{\boldsymbol{i}}$ is a vector of demographic controls including race indicators, categorical indicators for education levels to control for socioeconomic status, and a full set of age indicators, to control for the negative effect of age on the probability of being divorced or ever divorced. ${ }^{9}$ State $_{s}$ is a full set of indicators for the state the individual lived in as a youth, with $\eta_{s}$ the state-specific coefficient for each indicator, and $\varepsilon_{i}$ is the individual-specific error term.

Although the HRS is longitudinal, this is a cross-sectional regression. Because any law changes occurred before the survey was fielded, the exposure variables do not vary between respondents' observations, ruling out a fixed effects specification. The identifying assumption is that the change to a unilateral divorce regime in an individual's state of residence as a youth is orthogonal to her unobservable characteristics. ${ }^{10}$ The state fixed effects control for characteristics of the state which might contribute to the divorce climate, and account for the part of the variation in individuals' exposure to a unilateral divorce law which comes from the differential timing of the divorce law changes across states. Therefore with the state fixed effects the model is identified by variation within states in the age at exposure for individuals; these differences in exposure within states results from the different ages of the respondents when the law changed.

Column 1 of Table 3 gives means which show the proportion of the sample within each age-exposure category. The sample is well-distributed across the categories except that less than $1 \%$ of the sample (173 observations) were exposed to law changes at ages 0 - 15, mostly from the early-changing states Alaska, Oklahoma and New Mexico. Because this cell is so small results for this group should be viewed cautiously. Fortyseven percent lived in states where the laws never changed. In column 2 we see women who never experienced a law change do not have a significantly different likelihood of being divorced compared to the omitted category of women who were exposed to the law

\footnotetext{
${ }^{9}$ The decreasing likelihood of being divorced or ever-divorced with age can be seen in unreported tabulations of the HRS sample. This is consistent with documentation that divorce rates decrease with age and from younger to older cohorts (e.g., Clarke 1995).

${ }^{10}$ Friedberg (1998), Gruber (2004) and Stevenson (2007) among others have argued that this is the case.
} 
changed at age 36 and above (I will call this age group older adults). But exposure at younger ages increases this probability by 15 percentage points for exposure at 0-15 (children), 5 for exposure at 16-25 (young adults) and 2.5 for exposure at 26-35 (adults), although for the adult women the effect is significant only at $10 \%$. Age group effects are slightly larger for the ever-divorced specification in column 3. The coefficients for 16-25 year olds and 26-35 year olds in these two columns reflect percentage increase of 18-36\% over the baseline of 0.13 of women being currently divorced and 0.285 being everdivorced shown in Table 2. For men, there are no significant effects of exposure on being currently divorced, but exposure at 16-25 and 26-35 increases the probability of being ever-divorced, at the $10 \%$ level for $16-25$. For these age groups the coefficients are a 14$15 \%$ percentage increase from the baseline of 0.307 of men being ever-divorced in Table

2. The difference in results for men and women is consistent with a story where divorce law liberalization increases the likelihood of divorce for men and women exposed to them, but men are more able to remarry in the intervening period. ${ }^{11}$

\section{Results for Later Life Outcomes}

The specification for examining the effects of exposure on current outcomes is the same as equation 1 , except the dependent variable $W_{i}$ is the outcome measure in the survey year. This is a differences-in-differences approach where differences in later-life outcomes for older and younger cohorts (who were therefore exposed to divorce law changes at older and younger ages) in states where divorce laws changed are compared to outcome differences between older and younger cohorts in states which never changed their laws. First I will describe the results and then discuss them.

Labor Supply: Table 4 presents results for measures of labor supply, the first three columns for women and columns 4-6 for men. The first dependent variable is a

\footnotetext{
${ }^{11}$ The assumption in these specifications is that individuals were affected by the divorce law changes in the states they lived in. These effects could be mitigated if couples could obtain divorces out-of-state, termed "migratory divorce." States with permissive divorce laws or sympathetic judges were termed "divorce mills" in the pre-liberalization period (Plateris 1967 p. 9). Mexico was another alternative (Blake 1962 p. 162). Nevada in particular tailored its legislation to attract divorce seekers, who needed to reside in the state for only 6 weeks and did not need corroboration of the divorce grounds (Harmon 1999). Plateris (1967) estimated migratory divorces to comprise one out of 21 divorces in the U.S. in 1960, while Carter and Glick (1976) reckoned about one in ten in 1976. Anecdotal evidence suggests the incidence of migratory divorce decreased as divorce became more accessible and social norms changed in the divorce revolution period (Brown 2002, Phillips 1991 p. 219). In 1971 Mexico disallowed nonresidents from divorcing there (Time Magazine 1971). The impediment to obtaining a divorce from a neighboring, moreliberal state is the residency requirements: most states require residencies of 6 months or a year before they have jurisdiction over the divorce (Freed and Foster 1979, Matouschek and Rasul 2008).
} 
straightforward measure of current labor supply, an indicator for whether the respondent reports currently working for pay. The second considers the future working plans of those still working; it is the self-reported probability of working full-time after age 65, which is asked of workers under 65 . The third, also asked of workers, looks at the intensive margin and is a continuous measure of hours worked last week at the respondent's main job. The top panel examines the effect of law changes. Women exposed to a law change at ages 16-25 are more likely to be currently working and view themselves as more likely to work longer relative to the omitted category, but they work no more hours per week. Women exposed at ages 0-15 and 26-35 also appear more likely to work longer. The middle and lower panels show results from separate regressions of the same dependent variables with divorced and ever-divorced as the independent variables (with omitted categories not currently divorced and never-divorced, respectively). Although including these marital status variables introduces bias from both omitted variables and reverse causality with the outcomes, it may be useful to compare these correlations with the effects of changing laws. Being divorced or ever-divorced is associated with significant increases in the labor supply measure for women although the magnitudes for ever-divorced are slightly smaller. These effects for working for pay and probability of working past age 65 are roughly the same as the effect of exposure to law changes at aged 16-25. However, divorced and ever-divorced women work about 2 hours more per week hours relative to other women, whereas exposure to law changes makes no difference in hours worked.

In the results for men in columns $4-6$, exposure to law changes has no significant effects on labor supply, but being divorced or ever-divorced is associated with changes in the dependent variables. In contrast to women, divorced or ever-divorced men are less likely to be working for pay than other men, although the coefficient is only marginally significant for ever-divorced. This is consistent with evidence that those with poor labor market prospects are more likely to be divorced (e.g., South and Spitze 1986), and may be related to poorer health among the near-elderly divorced (Pienta et al. 1992). Among workers, however, the divorced and ever-divorced report a greater likelihood of working past age 65. For hours per week marital status make no difference.

Financial Status: The detailed financial questions in the HRS are directed to the household member most knowledgeable about the household's finances, and respondents 
are requested to choose among ranges for each variable if they are unwilling to specify exact amounts (Moon and Juster 1995, Smith 1995). The measures in Table 5 are respondent's own earnings; household income of the respondent and spouse if there is one, aggregated from information on 38 possible sources of household income (Moon and Juster 1995), such as labor earnings, capital income, private pensions and Social Security, disability, unemployment, welfare, food stamps, and veteran's benefits, and an "other" category which includes alimony; and net worth, which includes financial assets, equity in homes and other real estate, excluding secondary residences, and net value of businesses. Interestingly, exposure to liberalized laws at ages 16-25 affects the financial status of both men and women: earnings, income, and net worth all increase relative to the omitted group exposed at age 36 and older, and the effects are surprisingly large. For women exposed at ages 26-35, there is a slight decrease in earnings. The earnings results are robust to excluding nonworkers from the sample. Turning to the divorced and everdivorced panels, these two marital statuses have a positive association with women's earnings. The other associations in these panels are negative and mostly significant, evidence of the lower socioeconomic status associated with marital disruption ( e.g., Holden and Kuo 1996, Social Security Administration 2006). Although divorced women are more likely to work (Table 4) and have higher earnings, their household income and net worth are lower than their non-divorced counterparts. Divorced men have lower earnings, possibly because they are less likely to work for pay (Table 4), and also have lower household income and net worth.

Health: Table 6 shows measures for physical and mental health. For ease of comparison with the other outcomes, where a positive coefficient indicates an increase in labor supply or an increase in financial status, the health measures are coded so that an increase in magnitude indicates better health. Self-reported health status is coded from 1 to 5 for poor, fair, good, very good, and excellent health. Although self-reports of health are subjective, they are widely used, and have been found to correlate with objective measures of health and to predict morbidity and mortality (e.g., Grau et al. 1988, He et al. 2005). The mobility measure is an index of five tasks (walking several blocks, walking one block, walking across the room, climbing several flights of stairs, climbing one flight of stairs) and is coded as the number of these activities the respondent has no trouble with. Some of the questions in the mobility index are not asked of 1993 interviewees so 
they are excluded from this sample (St. Clair et al. 2006). The last measure is of mental health and is a score on the Center for Epidemiologic Studies Depression Scale (CES-D), a short self-report scale designed to measure depressive symptoms in the general population (Radloff 1977). The HRS collects a subset of the 20-item scale: six "negative" indicators (whether the respondent experienced the following all or most of the time: depression, everything is an effort, sleep is restless, felt alone, felt sad, and could not get going) and two "positive" indicators (whether the respondent felt happy and enjoyed life, all or most of the time) (St. Clair et al. 2006). Here CES-D is coded by adding one for each positive indicator and for the absence of each negative indicator; it ranges from 0 (has 6 depressive symptoms and reports no for the positive indicators) to 8 (is free of all 6 depressive symptoms and reports yes for the positive indicators).

The effects of exposure at ages 16-25 are negative for self-reported health status for both men and women, representing a 5\% decrease from the mean for women and $4 \%$ for men. For the mobility measure the coefficient is negative, but marginally significant only for women. For mental well-being, the coefficients are negative for the 16-25 exposure group, representing a $7 \%$ decrease for women and a $4 \%$ decrease for men.

Given the correlation of the divorce law liberalization with the incidence of divorce, it is tempting to use the divorce laws as an instrumental variable. Since the variation in the divorce laws occurred a number of years prior to measurement of the outcomes of interest, the power of such an instrument would likely be low. A potentially greater problem is the excludability of the divorce law changes. As Gruber (2004) has argued, it appears the divorce law liberalization affect behaviors in addition to divorce that could directly affect long-term outcomes. When I use the age-exposure variables as IVs for the specifications in Tables 3-6, the results (not shown) yield low F-statistics in the first stage and implausibly high coefficients in the second stage.

\section{Discussion}

Taken together, the results demonstrate that divorce law reform had substantial effects on the later-life outcomes of the young adults of that period, in addition to the suggestive evidence that exposure to the law changes for young adults increased their likelihood of divorcing. It appears that the reform affected long-term outcomes indirectly via changes in career and savings decisions, and not just through the increase in divorce. Given the association of divorce with lower financial status, we would expect exposure to 
law changes to decrease financial well-being if the increase in divorce were the only important effect of the reforms; but exposure to the law changes improves financial status in later life.

Divorce and divorce law-reform both affect women's labor supply in the same direction: women exposed to law changes at ages 16-25, and divorced and ever-divorced women are more likely to be working later in life and foresee continuing to work. But this increased labor supply confers increased wealth only for those exposed to the law changes, while divorced and ever-divorced women are poorer than their not-divorced and never-divorced counterparts despite working more. Further work is necessary to explore how the marital histories and career paths of these women diverged. But the results here suggest that as they saw the laws changing, young women in the divorce reform states changed their education and work investments in ways that increased their human and financial capital, relative to older women who had fewer labor market opportunities and relative to women in the states which never changed their laws. The spike in divorce resulting from the divorce law changes, although it may have been transitory, gave them the opportunity to improve their outside options.

Although men exposed to the divorce law liberalization as young adults are also better off financially than those exposed at older ages or never exposed, there is no evidence this worked through changes in their labor supply. It is perhaps not surprising that their later-life labor supply is unaffected, because men's labor supply is less sensitive than women's to a large number of influences; however the mechanisms that led to greater wealth need further examination. These men may have chosen more lucrative careers as results of the divorce law reforms, in order to maintain their bargaining position in a household where a wife's outside options were improving, or to remain competitive in case they had to re-enter the marriage market. Alternatively, they may be benefiting from their wives' increased earnings. Men who divorced may have had to increase their earnings and wealth acquisition to support children in the absence of the economies of scale that existed in the marriage. Mechoulan (2006) and Rasul (2006) suggest that after the switch to a unilateral divorce regime couples are better matched, which could also lead to wealth increases.

The results show that for both men and women, the effect of exposure to divorce law reform on health is negative, in the same direction as the associations with being 
divorced or ever-divorced. It is a bit puzzling that the coefficients for the exposure effects are so similar in magnitude to those for being divorced or ever-divorced. First, if health effects worked largely through the direct effect of getting divorced, we would expect the health effects from exposure to be smaller than the direct effects from divorce, since not everyone exposed did get divorced. We might also expect that deleterious health effects of divorce would be mitigated for the exposed groups, because the exposed groups are wealthier. Further research into these mechanisms in needed as well.

\section{More evidence on labor supply}

In this section I turn to March Current Population Survey (CPS) data from 1963 to 1999 to compare graphically the labor force participation (LFP) of women aged 15-62 in states which liberalized their laws and in those which never changed their laws. The advantage of the CPS is that it is a large, nationally representative dataset with information for each year over this time period. The drawback is that for the periods 1968-72 and 1973-76, some states were not individually coded in the data, but were put into two different groupings for the two time periods. Homogenous groups (all lawchanging states or all no-change states) are included in the data, but states in heterogeneous groupings drop in and out of the sample in the years 1968-1976. The CPS is a repeated series of cross-sections, which allows the tracking of "synthetic cohorts" over time (Lleras-Muney 2005). Although the same individuals cannot be followed over long periods of time in the CPS, cohort profiles can be plotted by grouping women observed in each calendar year by their birth years (here in 10-year spans), calculating their participation rates in that year, and linking these rates from year to year. Following cohorts allows disentangling life-cycle (or age) effects from generational (or cohort) differences. In Figure 2 each profile-pairing of a solid and a dashed line represents the experience of a cohort as it ages, with "age" denoted on the x-axis as the midpoint of the age range for the cohort in any given survey year. The oldest cohort shown in this figure was born between 1915 and 1924, the profile on the lower right, and the youngest was born between 1955 and 1964, on the upper left. Perhaps most striking is the acrosscohort increase in women's LFP - each profile is higher at any given age as we move from the lower right to the upper left and from older to younger cohorts. The second notable difference among cohorts is in the effects of living in states which changed their laws, represented by the solid line for each cohort, versus in no-change states, represented by 
the dashed line. First consider the middle profile, for the cohort born 1935-44. Since we first observe these women in 1963 (at ages 19-28), the first twelve years of their profile covers the most active period of divorce law liberalization, through 1975. At the beginning of this period, the LFP rate in the "never" states is greater, but the rate in the law-changing states overtakes it and is significantly greater for ages 31-47. This is suggestive that the law changes were associated with increased LFP by women, as they saw the likelihood of divorce spike for their cohort with the law changes. Contrast this with the older cohorts, born 1915-24 and 1925-34: again the first twelve years of the profile covers the liberalization period, but for these two cohorts there is no notable difference between the two lines. It seems likely that the law changes had little effect on LFP for these older cohorts for two reasons: with longer-lived and more stable marriages, the change in the risk of divorce was not as great, and their work options were likely more limited than those of younger women. For the 1945-54 cohort, the second youngest in the figure, the first twelve years of the profile show little difference for women in the two types of states. Around age 25, however, LFP for women in the law-changing states becomes greater than for women in no-change states, and this difference is significant for ages 27-42. This is consistent with women in the law-changing states choosing to work during their child-bearing ages (cf. Genadek, Stock, and Stoddard 2007). The youngest cohort, born 1955-64, comes of working age after the law changes are complete. The LFP for women in the law-changing states is higher for most of the years we observe them, significantly so for ages 15 - 31, suggesting that higher women's LFP has become a norm in these states.

The evidence is suggestive that the law changes had an important effect on the labor supply decisions of women who reached their mid-twenties during the divorce law liberalization and shortly thereafter. The effect appears to persist, although at a lower level, for the youngest cohort of women, for whom the law changes were in place by their midteens.

\section{Conclusion}

Marital status continues to be an important predictor of well-being (Waite and Gallagher 2000), and the increased proportion of divorced people in retiring cohorts is a challenge for policymakers (Ruggles 1997). Especially for older women, being divorced is correlated with poverty in old age (Haider, Jacknowitz, and Schoeni 2003). However, 
the evidence presented in this paper suggests that the divorce law liberalization of the 1960s and 1970s was not a major contributor either to the increasing number of divorced and ever-divorced older Americans, nor to the lower financial status associated with divorce among the elderly. In particular, women exposed to divorce law reform at ages 16-25 are earning more, have more wealth, and are more likely to foresee working past age 65 than are their counterparts who lived in states where the divorce laws did not change. Men exposed at these ages are also wealthier relative to other men. These measures bode well for their continued well-being as these groups age.

These improved outcomes are evidence against arguments that the Divorce Revolution was calamitous for everyone (Kirkwood 1996). Further evidence comes from Stevenson and Wolfers (2006), who found that divorce law liberalization reform reduced contemporaneous female suicide rates, domestic violence, and murder of women by their spouses. The long-term evaluation of this policy change remains complex, however. My results shows that the same groups whose later-life financial status is improved display diminished physical and mental health. Gruber (2004) presents evidence that children exposed to the law changes are less well educated and have lower family incomes as young adults.

The evidence in this study supports the argument that the divorce law changes had powerful unforeseen effects (Jacob 1988, Parkman 1994) and that these effects worked not only through increased divorce rates but through behavioral changes of those who did not divorce (Gruber 2004). Of note is that the law changes were beneficial financially to those who were young adults when exposed, but detrimental to the socioeconomic status of those exposed as children in Gruber's study. This is consistent with the possibility that within families trade-offs were made between marriage-specific investments (i.e., children) and individuals investments that would be more valuable if the marriage ended (i.e., women's increasing labor supply). Divorce law reform changed the terms of marriage contracts that couples were currently engaged in without consideration of the long term effects on incentives to make these investments.

\section{References}

Allen, Douglas. 1992. "Marriage and Divorce: Comment." American Economic Review 82(3):679-85.

Becker, Gary, Elizabeth Landes, and Robert T. Michael. 1977. "An Economic Analysis 
of Marital Instability." Journal of Political Economy 85(6):1141-87.

Blake, Nelson, 1962. The Road to Reno: a History of Divorce in the United States. New York, Macmillan.

Brinig, Margaret, and Frank H. Buckley. 1998. "No-Fault Laws and At-Fault People.” International Review of Law and Economics 18(3): 325-40.

Brown, Patricia Leigh. 2002 (April 28) "Ex-Divorce Capital Keeping Landmarks." Houston, TX: Houston Chronicle p. 11.

Burtless, Gary and Joseph Quinn. 2002. "Is Working Longer the Answer for an Aging Workforce?" Boston College Center for Research Retirement Issue in Brief \#11.

Carter, Hugh and Paul Glick. 1976. Marriage and Divorce: A Social and Economic Study. Cambridge: Harvard University Press.

Cherlin, Andrew. 1992. Marriage, Divorce, Remarriage. Cambridge: Harvard University Press.

Chiappori, Pierre-Andre, Bernard Fortin and Guy Lacroix. 2002. "Marriage Market, Divorce Legislation and Household Labor Supply." Journal of Political Economy 10(1):37-72.

Chiappori, Pierre-Andre, Murat Iyigun, and Yoram Weiss. 2007. "Public Goods, Transferable Utility and Divorce Laws." Mimeo.

Clarke, Sally. 1995. "Advance Report of Final Divorce Statistics, 1989 and 1990." Monthly Vital Statistics Report, vol 43, No. 8, supplement, Hyattsville, Maryland: National Center for Health Statistics.

Coase, Ronald. 1960. "The Problem of Social Cost." Journal of Law and Economics 3:1-44.

Council on Families in America. 1995. "Marriage in America: A Report to the Nation." New York: Institute for American Values.

Ellman, Ira. 2000. "Divorce Rates, Marriage Rates, and the Problematic Persistence of Marital Roles.” Family Law Quarterly, 34(1): 1-42.

Ellman, Ira, and Sharon Lohr. 1998. "Dissolving the Relationship between Divorce Laws and Divorce Rates.” International Review of Law and Economics, 18(3): 341-59.

Freed, Doris, and Henry H. Foster. 1979. "Divorce in the Fifty States: An Overview as of 1978." Family Law Quarterly 13(1):105-28.

Friedberg, Leora. 1998. "Did Unilateral Divorce Raise Divorce Rates? Evidence from Panel Data.” American Economic Review. 88(3).

Genadek, Katie, Wendy Stock and Christiana Stoddard. 2007. "No-Fault Divorce Laws and the Labor Supply of Women with and Without Children." Journal of Human Resources 42(1):247-274.

Glenn, Norval. 1997. "A Reconsideration of the Effect of No-Fault Divorce on Divorce Rates.” Journal of Marriage and the Family, 59(4):1023-25.

Grau, Lois, Bernadette West, and Patrice Gregory. 1988. "How Do You Feel? SelfReported Health as An Indicator of Current Physical and Mental Health Status." Journal of Psychosocial Nursing and Mental Health Services 36: 24-30.

Gruber, Jonathan. 2004. "Is Making Divorce Easier Bad for Children? The Long Run Implications of Unilateral Divorce." Journal of Labor Economics 22(4):799-833.

Haider, Steven, Alison Jacknowitz, and Robert Schoeni. 2003. "The Economic Status of Elderly Divorced Women." University of Michigan Research Retirement Center Working Paper WP 2003-046.

Harmon, Mella Rothwell. 1999 (Spring). "Getting Renovated: Reno Divorces in the 
1930s." Nevada Historical Society Quarterly.

He, Wan, Manisha Sengupta, Victoria Velkoff, and Kimberly DeBarros. 2005. "65+ in the United States: 2005." U.S. Census Bureau, Current Population Reports, P23209, U.S. Government Printing Office, Washington, DC.

Hetherington, E. Mavis. 2002 (April 8). "Marriage and Divorce American Style: A destructive marriage is not a happy family.” The American Prospect.

Holden, Karen and Hsiang-Hui Daphne Kuo. 1996. "Complex Marital Histories and Economic Well-being: The continuing legacy of divorce and widowhood as the HRS cohort approaches retirement .” The Gerontologist 36:383-90.

Jacob, Herbert. 1988. Silent Revolution: The Transformation of Divorce Law in the United States. Chicago: University of Chicago Press.

Johnson, William and Jonathan Skinner. 1986. "Labor supply and Marital Separation.” American Economic Review 76(3):455-6.

Kirkwood, Cort. 1996 (June 17). "No-fault divorces under increasing attack" Insight on the News.

Lleras-Muney, Adriana. 2005. “The Relationship Between Education and Adult Mortality in the United States.” Review of Economic Studies 72: 189-221.

Matouschek, Niko and Imran Rasul. 2008. "The Economics of the Marriage Contract: Theories and Evidence." Journal of Law and Economics 51(1).

McNamara, Tay, Regina O'Grady-LeShane, and John B. Williamson. 2003. "The Role of Marital History, Early Retirement Benefits, and the Economic Status of Women.” Center for Retirement Research at Boston College Working Paper.

Mechoulan, Stéphane. 2006. "Divorce Laws and the Structure of the American Family." Journal of Legal Studies 35(1): 143-74.

. 2005. "Economic Theory’s Stance On No-Fault Divorce." Review of the Economics of the Household 3: 337-359.

Moon, Marilyn and F. Thomas Juster . 1995. "Economic Status Measures in the Health and Retirement Study." Journal of Human Resources 30: S138-S157.

Munnell, Alicia and Natalia Jivan. 2005. “What Makes Older Women Work?”. Work Opportunities Brief 1. Center for Retirement Research at Boston College.

Nakonezny, Paul, Robert Shull, and Joseph L. Rodgers. 1995. "The Effect of No-Fault Divorce Law on the Divorce Rate across the 50 States and Its Relation to Income, Education and Religiosity.” Journal of Marriage and the Family, 57(2): 477-88.

Page, Marianne, and Ann Stevens. 2004. "The Economic Consequences of Absent Parents." Journal of Human Resources 39(1):80-107.

Papps, Kerry. 2006. “The Effects of Divorce Risk on the Labour Supply of Married Couples.” IZA (Forschungsinstitut zur Zukunft der Arbeit/Institute for the Study of Labor) Discussion Paper No. 2395.

Parkman, Allen. 1993. "Terms of Endearment," Reason, 25(2), June 1993, 29-33.

Peters, H. Elizabeth. 1992. "Marriage and Divorce: Reply. "American Economic Review 82(3):686-93. . 1986. "Marriage and Divorce: Informational Constraints and Private Contracting. " American Economic Review 76(3):437-54.

Phillips, Roderick. 1991. Untying the Knot: A Short History of Divorce. Cambridge University Press.

Pienta, Amy, Mark Hayward, and Kristi Jenkins. 2000. "Health Consequences of Marriage for the Retirement Years." Journal of Family Issues 21: 559-586. 
Plateris, Alexander. 1967. “Divorce Statistics Analysis, United States-1963.” Vital and Health Statistics, National Center for Health Statistics, Public Health Service Publication No. 1000, Series 21, No. 13. U.S. Department of Health, Education, and Welfare.

Pollitt, Katha. 1997 (June 27). "What's Right About Divorce." New York Times.

Radloff, Lenore. 1977. "The CES-D scale: A self-report depression scale for research in the general population." Applied Psychological Measurement 1(3):385-401.

Rasul, Imran. 2006. “Marriage markets and divorce laws.” Journal of Law, Economics, and Organization 22(1):30-69.

Riley, Glenda. 1991. Divorce: An American Tradition. Oxford: Oxford University Press.

Rodgers, Joseph L., Paul Nakonezny, and Robert Shull. 1999. “Did No-Fault Divorce Legislation Matter? Definitely Yes and Sometimes No.” Journal of Marriage and the Family, 61(3): 803-9.

Ruggles, Steven. 1997. "The Rise of Divorce and Separation in the United States, 18801990,” Demography 34(4):455-466.

St.Clair, Patricia, Darlene Blake, Delia Bugliari, Sandy Chien, Orla Hayden, Michael Hurd, Serhii Ilchuk, Fuan-Yue Kung, Angela Miu, Constantijn Panis, Philip Pantoja, Afshin Rastegar, Susann Rohwedder, Elizabeth Roth, Joanna Wedell, and Julie Zissimopoulos. 2006. "RAND HRS Data Documentation, Version F."

Smith, James P. 1995. "Economic Racial and Ethnic Differences in Wealth in the Health and Retirement Study." Journal of Human Resources 30: S158-S183.

Sepler, Harvey. 1981. "Measuring the Effects of No-Fault Divorce Laws Across Fifty States: Quantifying a Zeitgeist.” Family Law Quarterly 15(1): 65-102.

Social Security Administration. 2006. Income of the Population 55 or Older, 2004. SSA Publication No. 13-11871. Washington, D.C.: Social Security Administration.

South, Scott, and Glenna Spitze. 1986. "Determinants of Divorce over the Marital Life Course." American Sociological Review 51(4):583-590.

Stevenson, Betsey. 2007. “The Impact of Divorce Laws on Marriage-Specific Capital.” Journal of Labor Economics 25(1):75 -94.

Stevenson, Betsey. No date "Divorce Law and Women's Labor Supply." Mimeo.

Stevenson, Betsey, and Justin Wolfers. 2006. "Bargaining in the Shadow of the Law:

Divorce Laws and Family Distress." Quarterly Journal of Economics 121(1):267288.

Time Magazine. 1971 (August 30). "Divorce, Caribbean Style."

Waite, Linda and Maggie Gallagher. 2000. The Case for Marriage. New York: Broadway Books.

Weitzman, Lenore. 1985. The Divorce Revolution : the Unexpected Social and Economic Consequences for Women and Children in America. New York : Free Press.

Whitehead, Barbara. 1997. The Divorce Culture. New York: Knopf. 1993 (April). “Dan Quayle Was Right.” The Atlantic Monthly pp. 47-84.

Wilson, Barbara and Sally Clarke. 1992. "Remarriages: A demographic profile.” Journal of Family Issues 13(2): 123-141.

Wolfers, Justin. 2006. "Did Unilateral Divorce Raise Divorce Rates? A Reconciliation and New Results.” American Economic Review 96(5):1802-1820. 

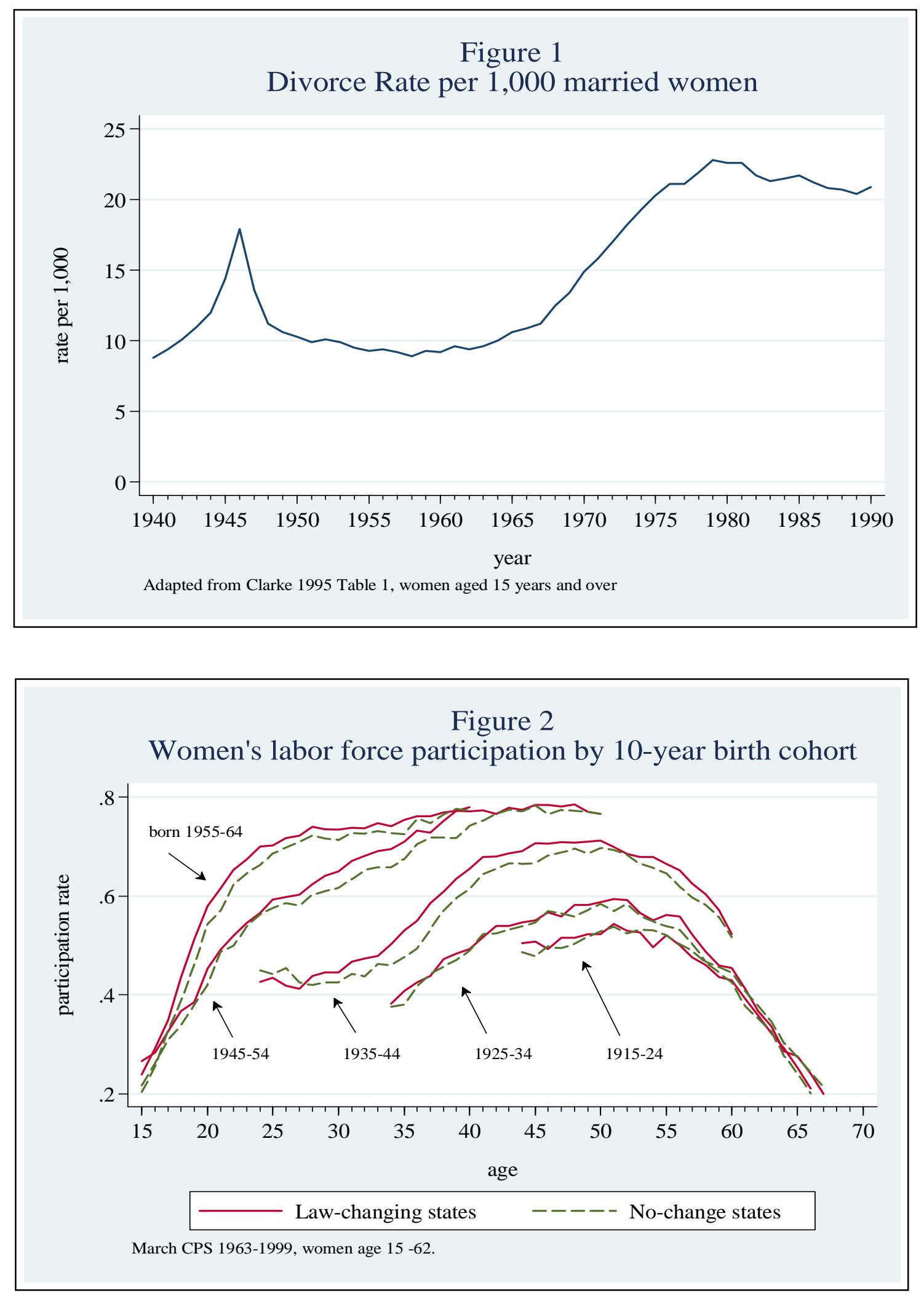
Table 1

States' changes to unilateral divorce

\begin{tabular}{lllll}
\hline \multicolumn{1}{c}{$\begin{array}{c}\text { States Which Never } \\
\text { Changed }\end{array}$} & \multicolumn{2}{c}{ State and Year Changed to Unilateral Divorce } \\
\hline \hline State & State & Year & State & Year \\
\cline { 5 - 6 } \cline { 5 - 5 } Arkansas & New Mexico & 1933 & Kentucky & 1972 \\
District of Columbia & Alaska & 1935 & Michigan & 1972 \\
Illinois & Oklahoma & 1953 & Nebraska & 1972 \\
Louisiana & Nevada & 1967 & Arizona & 1973 \\
Maryland & Delaware & 1968 & Connecticut & 1973 \\
Mississippi & Kansas & 1969 & Georgia & 1973 \\
Missouri & California & 1970 & Indiana & 1973 \\
New Jersey & Iowa & 1970 & Maine & 1973 \\
New York & Texas & 1970 & Montana & 1973 \\
North Carolina & Alabama & 1971 & Washington & 1973 \\
Ohio & Florida & 1971 & Minnesota & 1974 \\
Pennsylvania & Idaho & 1971 & Massachusetts & 1975 \\
South Carolina & New Hampshire & 1971 & Rhode Island & 1975 \\
Tennessee & North Dakota & 1971 & Wyoming & 1977 \\
Vermont & Oregon & 1971 & Wisconsin & 1978 \\
Virginia & Colorado & 1972 & South Dakota & 1985 \\
West Virginia & Hawaii & 1972 & Utah & 1987 \\
\hline Notes: Adapted from Gruber (2004) Table 1. & & & \\
\hline
\end{tabular}


Table 2

Sample Summary Statistics

\begin{tabular}{|c|c|c|c|}
\hline & 1 & 2 & 3 \\
\hline & $\begin{array}{l}\text { Whole } \\
\text { sample }\end{array}$ & Women & Men \\
\hline & {$[23,935]$} & {$[13,365]$} & {$[10,570]$} \\
\hline age & 61.53 & 62.12 & 60.84 \\
\hline & $(9.32)$ & $(10.90)$ & (9.73) \\
\hline years of education & 12.60 & 12.44 & 12.77 \\
\hline & $(2.73)$ & (2.91) & (3.16) \\
\hline$=1$ if married & 0.669 & 0.585 & 0.776 \\
\hline & $(0.422)$ & $(0.502)$ & $(0.414)$ \\
\hline$=1$ if divorced & 0.119 & 0.130 & 0.108 \\
\hline & $(0.291)$ & $(0.342)$ & $(0.303)$ \\
\hline$=1$ if separated & 0.023 & 0.024 & 0.022 \\
\hline & $(0.134)$ & $(0.155)$ & $(0.144)$ \\
\hline$=1$ if widowed & 0.144 & 0.221 & 0.055 \\
\hline & $(0.315)$ & $(0.423)$ & $(0.222)$ \\
\hline$=1$ if never married & 0.042 & 0.038 & 0.046 \\
\hline & $(0.180)$ & (0.195) & $(0.206)$ \\
\hline$=1$ if ever-divorced & 0.295 & 0.285 & 0.307 \\
\hline & $(0.409)$ & $(0.460)$ & $(0.451)$ \\
\hline household size & 2.35 & 2.24 & 2.48 \\
\hline & (1.06) & (1.18) & (1.16) \\
\hline Observations & 23,935 & 13,365 & 10,570 \\
\hline \multicolumn{4}{|c|}{$\begin{array}{l}\text { Notes: HRS sample includes first positively weighted observations } \\
\text { for each respondent born before } 1954 \text { and aged } 51-90 \text { at the time of } \\
\text { the interview, who lived in the United Sates as a youth and has non- } \\
\text { missing geographic information. Standard deviations reported in } \\
\text { parentheses. Means are weighted with the respondent sample } \\
\text { weight. }\end{array}$} \\
\hline
\end{tabular}


Table 3

Law changes and divorce status

\begin{tabular}{|c|c|c|c|c|c|}
\hline & 1 & 2 & 3 & 4 & 5 \\
\hline & Means & \multicolumn{4}{|c|}{ Linear Probability Models } \\
\hline & Whole & \multicolumn{2}{|c|}{ Women } & \multicolumn{2}{|c|}{ Men } \\
\hline & $\begin{array}{l}\text { Proportion } \\
\text { in this } \\
\text { category }\end{array}$ & $\begin{array}{l}\text { Currently } \\
\text { divorced }\end{array}$ & $\begin{array}{c}\text { Ever- } \\
\text { divorced }\end{array}$ & $\begin{array}{l}\text { Currently } \\
\text { divorced }\end{array}$ & $\begin{array}{c}\text { Ever- } \\
\text { divorced }\end{array}$ \\
\hline Law never changed & $\begin{array}{c}0.469 \\
{[0.454]}\end{array}$ & $\begin{array}{c}0.028 \\
(0.026)\end{array}$ & $\begin{array}{c}0.027 \\
(0.036)\end{array}$ & $\begin{array}{c}0.003 \\
(0.037)\end{array}$ & $\begin{array}{c}-0.017 \\
(0.048)\end{array}$ \\
\hline Law changed at age $0-15$ & $\begin{array}{c}0.009 \\
{[0.086]}\end{array}$ & $\begin{array}{c}0.147 * * \\
(0.065)\end{array}$ & $\begin{array}{c}0.158 * \\
(0.083)\end{array}$ & $\begin{array}{c}-0.016 \\
(0.075)\end{array}$ & $\begin{array}{c}0.120 \\
(0.096)\end{array}$ \\
\hline Law changed at age $16-25$ & $\begin{array}{c}0.140 \\
{[0.316]}\end{array}$ & $\begin{array}{c}0.047 * * \\
(0.017)\end{array}$ & $\begin{array}{c}0.069 * * * \\
(0.022)\end{array}$ & $\begin{array}{c}0.018 \\
(0.019)\end{array}$ & $\begin{array}{l}0.043^{*} \\
(0.025)\end{array}$ \\
\hline Law changed at age $26-35$ & $\begin{array}{c}0.139 \\
{[0.314]}\end{array}$ & $\begin{array}{l}0.025^{*} \\
(0.015)\end{array}$ & $\begin{array}{c}0.051 * * * \\
(0.019)\end{array}$ & $\begin{array}{c}0.021 \\
(0.016)\end{array}$ & $\begin{array}{c}0.048 * * \\
(0.021)\end{array}$ \\
\hline Law changed age 36 and up & $\begin{array}{c}0.243 \\
{[0.390]}\end{array}$ & & & & \\
\hline Observations & 23,935 & 13,365 & 13,365 & 10,570 & 10,570 \\
\hline $\mathrm{R}^{2}$ & & 0.06 & 0.14 & 0.05 & 0.11 \\
\hline \multicolumn{6}{|c|}{$\begin{array}{l}\text { Notes: Standard errors reported in parentheses, standard deviations in brackets. Results are } \\
\text { weighted with the respondent sample weight. Sample is first recorded positively weighted } \\
\text { observation for HRS respondents aged 51-90. Regressions include indicators for education (high } \\
\text { school graduate, some college, college or more, and missing education information, with less than } \\
\text { high school omitted), race (white and black with other omitted), age (age } 51 \text { omitted), and fixed } \\
\text { effects for state lived in as a youth. }\end{array}$} \\
\hline
\end{tabular}


Table 4

Labor supply

\begin{tabular}{|c|c|c|c|c|c|c|}
\hline & 1 & 2 & 3 & 4 & 5 & 6 \\
\hline & \multicolumn{3}{|c|}{ Women } & \multicolumn{3}{|c|}{ Men } \\
\hline & $\begin{array}{l}\text { Working for } \\
\text { pay }\end{array}$ & $\begin{array}{c}\text { Probability } \\
\text { of working } \\
\text { past } 65\end{array}$ & $\begin{array}{l}\text { Hours/week } \\
\text { at main job }\end{array}$ & $\begin{array}{l}\text { Working for } \\
\text { pay }\end{array}$ & $\begin{array}{c}\text { Probability } \\
\text { of working } \\
\text { past } 65\end{array}$ & $\begin{array}{c}\text { Hours/week } \\
\text { at main job }\end{array}$ \\
\hline Law never changed & $\begin{array}{c}-0.001 \\
(0.0340)\end{array}$ & $\begin{array}{l}-0.008 \\
(0.048)\end{array}$ & $\begin{array}{c}0.84 \\
(1.63)\end{array}$ & $\begin{array}{l}-0.065 \\
(0.040)\end{array}$ & $\begin{array}{l}-0.03 \\
(0.05)\end{array}$ & $\begin{array}{l}-0.94 \\
(1.66)\end{array}$ \\
\hline Law changed at age $0-15$ & $\begin{array}{c}0.037 \\
(0.075)\end{array}$ & $\begin{array}{c}0.206 * * \\
(0.103)\end{array}$ & $\begin{array}{l}-4.48 \\
(3.64)\end{array}$ & $\begin{array}{l}-0.108 \\
(0.092)\end{array}$ & $\begin{array}{l}(0.01) \\
(0.11)\end{array}$ & $\begin{array}{l}-0.99 \\
(4.26)\end{array}$ \\
\hline Law changed at age $16-25$ & $\begin{array}{c}0.054^{* * *} \\
(0.020)\end{array}$ & $\begin{array}{c}0.089 * * * \\
(0.024)\end{array}$ & $\begin{array}{c}0.04 \\
(0.89)\end{array}$ & $\begin{array}{c}-0.027 \\
(0.020)\end{array}$ & $\begin{array}{l}(0.00) \\
(0.03)\end{array}$ & $\begin{array}{l}-0.81 \\
(0.84)\end{array}$ \\
\hline Law changed at age 26-35 & $\begin{array}{c}0.028 \\
(0.017)\end{array}$ & $\begin{array}{c}0.049 * * \\
(0.022)\end{array}$ & $\begin{array}{c}0.98 \\
(0.83)\end{array}$ & $\begin{array}{l}-0.007 \\
(0.017)\end{array}$ & $\begin{array}{c}0.02 \\
(0.02)\end{array}$ & $\begin{array}{c}0.15 \\
(0.77)\end{array}$ \\
\hline Observations & 13,338 & 4,800 & 5,432 & 10,554 & 4,634 & 5,670 \\
\hline $\mathrm{R}^{2}$ & 0.37 & 0.04 & 0.13 & 0.40 & 0.03 & 0.18 \\
\hline Divorced & $\begin{array}{c}0.090 * * * \\
(0.014)\end{array}$ & $\begin{array}{c}0.116^{* * *} \\
(0.015)\end{array}$ & $\begin{array}{c}2.78 * * * \\
(0.490)\end{array}$ & $\begin{array}{c}-0.048 * * * \\
(0.018)\end{array}$ & $\begin{array}{c}0.08 * * * \\
(0.021)\end{array}$ & $\begin{array}{l}-1.07 \\
(0.69)\end{array}$ \\
\hline Ever-divorced & $\begin{array}{c}0.043^{* * *} \\
(0.011)\end{array}$ & $\begin{array}{c}0.088 * * * \\
(0.011)\end{array}$ & $\begin{array}{c}2.27 * * * \\
(0.417)\end{array}$ & $\begin{array}{c}-0.019 * \\
(0.011)\end{array}$ & $\begin{array}{c}0.05 * * * \\
(0.013)\end{array}$ & $\begin{array}{c}0.61 \\
(0.44)\end{array}$ \\
\hline $\begin{array}{l}\text { Mean of dependent variable: } \\
\text { [standard deviation] }\end{array}$ & $\begin{array}{c}0.467 \\
{[0.509]}\end{array}$ & $\begin{array}{c}0.260 \\
{[0.327]}\end{array}$ & $\begin{array}{c}36.83 \\
{[13.65]}\end{array}$ & $\begin{array}{c}0.611 \\
{[0.476]}\end{array}$ & $\begin{array}{c}0.327 \\
{[0.341]}\end{array}$ & $\begin{array}{c}43.47 \\
{[13.74]}\end{array}$ \\
\hline
\end{tabular}

Notes: see notes to Table 3. Ordinary least squares regressions. Here regressors also include household size. Sample sizes are the same and $\mathrm{R}^{2}$ are similar for the three panels. 
Table 5

Earnings and assets

\begin{tabular}{|c|c|c|c|c|c|c|}
\hline & 1 & 2 & 3 & 4 & 5 & 6 \\
\hline & \multicolumn{3}{|c|}{ Women } & \multicolumn{3}{|c|}{ Men } \\
\hline & $\begin{array}{c}\text { Respondent } \\
\text { Earnings }\end{array}$ & $\begin{array}{c}\text { Total } \\
\text { household } \\
\text { income } \\
\end{array}$ & Net worth & $\begin{array}{c}\text { Respondent } \\
\text { Earnings }\end{array}$ & $\begin{array}{c}\text { Total } \\
\text { household } \\
\text { income } \\
\end{array}$ & Net worth \\
\hline Law never changed & $\begin{array}{c}457 \\
(1,267)\end{array}$ & $\begin{array}{c}3,508 \\
(3,164)\end{array}$ & $\begin{array}{c}19,869 \\
(21,599)\end{array}$ & $\begin{array}{l}-1,586 \\
(7,569)\end{array}$ & $\begin{array}{c}11,942 \\
(10,993)\end{array}$ & $\begin{array}{c}72,728 \\
(61,632)\end{array}$ \\
\hline Law changed at age $0-15$ & $\begin{array}{c}4,932 \\
(3,631)\end{array}$ & $\begin{array}{c}19,389 \\
(19,516)\end{array}$ & $\begin{array}{c}138,055 \\
(118,266)\end{array}$ & $\begin{array}{c}2,446 \\
(7,875)\end{array}$ & $\begin{array}{l}23,478 * \\
(13,243)\end{array}$ & $\begin{array}{c}36,975 \\
(71,741)\end{array}$ \\
\hline Law changed at age 16-25 & $\begin{array}{c}7,440 * * * \\
(1,189)\end{array}$ & $\begin{array}{c}26,637 * * * \\
(3,903)\end{array}$ & $\begin{array}{c}96,442 * * * \\
(28,793)\end{array}$ & $\begin{array}{c}15,185 * * * \\
(4,554)\end{array}$ & $\begin{array}{c}27,481^{* * *} \\
(7,014)\end{array}$ & $\begin{array}{c}121,637 * * * \\
(37,600)\end{array}$ \\
\hline Law changed at age $26-35$ & $\begin{array}{c}-2,109 * * * \\
(754)\end{array}$ & $\begin{array}{c}-2,285 \\
(2,422)\end{array}$ & $\begin{array}{c}17,306 \\
(26,309)\end{array}$ & $\begin{array}{l}-1,646 \\
(1,888)\end{array}$ & $\begin{array}{c}6,293 \\
(7,290)\end{array}$ & $\begin{array}{c}-17,311 \\
(29,720)\end{array}$ \\
\hline Observations & 13,365 & 13,365 & 13,365 & 10,570 & 10,570 & 10,570 \\
\hline $\mathrm{R}^{2}$ & 0.27 & 0.18 & 0.10 & 0.13 & 0.10 & 0.08 \\
\hline Divorced & $\begin{array}{c}3,988 * * * \\
(809)\end{array}$ & $\begin{array}{c}-27,645 * * * \\
(1,815)\end{array}$ & $\begin{array}{c}-154,582 * * * \\
(13,329)\end{array}$ & $\begin{array}{c}-6,544 * * * \\
(1,684)\end{array}$ & $\begin{array}{c}-16,314 * * * \\
(3,414)\end{array}$ & $\begin{array}{c}-106,352 * * * \\
(20,537)\end{array}$ \\
\hline Ever-divorced & $\begin{array}{c}2,419 * * * \\
(600)\end{array}$ & $\begin{array}{c}-8,715 * * * \\
(2,236)\end{array}$ & $\begin{array}{c}-82,670 * * * \\
(16,909)\end{array}$ & $\begin{array}{c}-3,499 * * \\
(1,476)\end{array}$ & $\begin{array}{l}-4,485 \\
(2,858)\end{array}$ & $\begin{array}{l}-35,720 * \\
(19,495)\end{array}$ \\
\hline $\begin{array}{l}\text { Mean of dependent variable: } \\
\text { [standard deviation] }\end{array}$ & $\begin{array}{c}10,998 \\
{[21,281]}\end{array}$ & $\begin{array}{c}44,101 \\
{[74,826]}\end{array}$ & $\begin{array}{c}216,694 \\
{[533,295]}\end{array}$ & $\begin{array}{c}24,240 \\
{[54,059]}\end{array}$ & $\begin{array}{c}56,312 \\
{[110,415]}\end{array}$ & $\begin{array}{c}260,959 \\
{[594,810]}\end{array}$ \\
\hline
\end{tabular}




\begin{tabular}{|c|c|c|c|c|c|c|}
\hline \multicolumn{7}{|c|}{$\begin{array}{l}\text { Table } 6 \\
\text { Health }\end{array}$} \\
\hline & 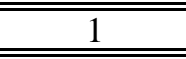 & 2 & 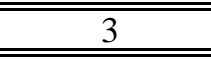 & 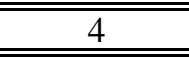 & 5 & 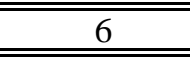 \\
\hline & \multicolumn{3}{|c|}{ Women } & \multicolumn{3}{|c|}{ Men } \\
\hline & $\begin{array}{l}\text { Self- } \\
\text { Reported } \\
\text { Health } \\
\text { Status } \\
\end{array}$ & Mobility & $\begin{array}{l}\text { Mental well- } \\
\text { being }\end{array}$ & $\begin{array}{l}\text { Self- } \\
\text { Reported } \\
\text { Health } \\
\text { Status } \\
\end{array}$ & Mobility & $\begin{array}{l}\text { Mental well } \\
\text { being }\end{array}$ \\
\hline Law never changed & $\begin{array}{c}-0.109 \\
(0.0870)\end{array}$ & $\begin{array}{l}-0.140 \\
(0.134)\end{array}$ & $\begin{array}{l}-0.257 \\
(0.162)\end{array}$ & $\begin{array}{l}-0.074 \\
(0.115)\end{array}$ & $\begin{array}{l}-0.162 \\
(0.122)\end{array}$ & $\begin{array}{c}0.001 \\
(0.172)\end{array}$ \\
\hline Law changed at age $0-15$ & $\begin{array}{c}0.005 \\
(0.213)\end{array}$ & $\begin{array}{l}-0.315 \\
(0.287)\end{array}$ & $\begin{array}{c}-0.800 * * \\
(0.391)\end{array}$ & $\begin{array}{l}-0.071 \\
(0.244)\end{array}$ & $\begin{array}{c}0.124 \\
(0.285)\end{array}$ & $\begin{array}{l}-0.437 \\
(0.430)\end{array}$ \\
\hline Law changed at age $16-25$ & $\begin{array}{c}-0.156^{* * *} \\
(0.0503)\end{array}$ & $\begin{array}{l}-0.111^{*} \\
(0.066)\end{array}$ & $\begin{array}{c}-0.484^{* * *} \\
(0.094)\end{array}$ & $\begin{array}{c}-0.132 * * \\
(0.058)\end{array}$ & $\begin{array}{l}-0.089 \\
(0.062)\end{array}$ & $\begin{array}{c}-0.289 * * * \\
(0.097)\end{array}$ \\
\hline Law changed at age 26-35 & $\begin{array}{c}0.04 \\
(0.0440)\end{array}$ & $\begin{array}{c}0.023 \\
(0.059)\end{array}$ & $\begin{array}{c}-0.037 \\
(0.077)\end{array}$ & $\begin{array}{c}-0.014 \\
(0.050)\end{array}$ & $\begin{array}{l}-0.018 \\
(0.054)\end{array}$ & $\begin{array}{c}-0.038 \\
(0.077)\end{array}$ \\
\hline Observations & 13,358 & 9,512 & 12,922 & 10,568 & 8,055 & 9,721 \\
\hline $\mathrm{R}^{2}$ & 0.15 & 0.08 & 0.08 & 0.15 & 0.08 & 0.08 \\
\hline Divorced & $\begin{array}{c}-0.209 * * * \\
(0.039)\end{array}$ & $\begin{array}{c}-0.181^{* * *} \\
(0.047)\end{array}$ & $\begin{array}{c}-0.419 * * * \\
(0.072)\end{array}$ & $\begin{array}{c}-0.109 * * \\
(0.052)\end{array}$ & $\begin{array}{c}-0.124^{* *} \\
(0.052)\end{array}$ & $\begin{array}{c}-0.475^{* * *} \\
(0.093)\end{array}$ \\
\hline Ever-divorced & $\begin{array}{c}-0.188 * * * \\
(0.028)\end{array}$ & $\begin{array}{c}-0.217 * * * \\
(0.034)\end{array}$ & $\begin{array}{c}-0.344 * * * \\
(0.051)\end{array}$ & $\begin{array}{c}-0.131 * * * \\
(0.032)\end{array}$ & $\begin{array}{c}-0.166 * * * \\
(0.033)\end{array}$ & $\begin{array}{c}-0.310 * * * \\
(0.054)\end{array}$ \\
\hline $\begin{array}{l}\text { Mean of dependent variable: } \\
\text { [standard deviation] }\end{array}$ & $\begin{array}{c}3.285 \\
{[1.200]}\end{array}$ & $\begin{array}{l}4.188 \\
{[1.311]}\end{array}$ & $\begin{array}{c}6.55 \\
{[1.97]}\end{array}$ & $\begin{array}{c}3.337 \\
{[1.170]}\end{array}$ & $\begin{array}{c}4.473 \\
{[1.092]}\end{array}$ & $\begin{array}{c}6.851 \\
{[1.683]}\end{array}$ \\
\hline $\begin{array}{l}\text { Notes: see notes to Table } 4 . \mathrm{S} \\
\text { number of activities responde } \\
\text { mobility scale and are exclud } \\
\text { depressive symptoms) to } 8 \text { (fe }\end{array}$ & $\begin{array}{l}\text { reported h } \\
\text { as no troul } \\
\text { rom that si } \\
\text { st depressi }\end{array}$ & $\begin{array}{l}\text { status is C } \\
\text { ith out of } \\
\text { The CE } \\
\text { mptoms). }\end{array}$ & score for $\mathrm{m}$ & $\begin{array}{l}\text { o } 5 \text { for exc } \\
\text { rviewees a } \\
\text { well-bein }\end{array}$ & $\begin{array}{l}\text { Mobility } \\
\text { t asked all } \\
\text { ges from } 0\end{array}$ & $\begin{array}{l}\text { coded as the } \\
\text { ms in the } \\
\text { lost }\end{array}$ \\
\hline
\end{tabular}




\section{RECENT WORKING PAPERS FROM THE}

\section{CENTER FOR RETIREMENT RESEARCH AT BOSTON COLLEGE}

The Response of Household Saving to the Large Shock of German Reunification Nicola Fuchs-Schündeln, November 2008

A Parsimonious Choquet Model of Subjective Life Expectancy

Alexander Ludwig and Alexander Zimper, November 2008

Risky Pensions and Household Saving Over the Life Cycle

David A. Love and Paul A. Smith, November 2008

Identifying Local Differences in Retirement Patterns

Leora Friedberg, Michael Owyang, and Anthony Webb, November 2008

What Effect Do Time Constraints Have on the Age of Retirement?

Leora Friedberg, Wei Sun, Anthony Webb, November 2008

Dual-Eligible Medicaid Spending: Are We on the Flat of the Curve?

Melissa A. Boyle, Joanna N. Lahey, and Margaret E. Czervionke, November 2008

Public Long-Term Care Insurance and the Housing and Living Arrangements of the Elderly: Evidence from Medicare Home Health Benefits

Gary V. Engelhardt and Nadia Greenhalgh-Stanley, November 2008

The Impact of Changing Earnings Volatility on Retirement Wealth

Austin Nichols and Melissa M. Favreault, November 2008

The Housing Bubble and Retirement Security

Alicia H. Munnell and Mauricio Soto, with the assistance of Jean-Pierre Aubry, November 2008

How Much Do State and Economic and Other Characteristics Affect Retirement Behavior?

Alicia H. Munnell, Mauricio Soto, Robert K. Triest, and Natalia A. Zhivan, August 2008

Will People Be Healthy Enough to Work Longer?

Alicia H. Munnell, Mauricio Soto, and Alex Golub-Sass, August 2008

All working papers are available on the Center for Retirement Research website

(http://www.bc.edu/crr) and can be requested by e-mail (crr@bc.edu) or phone (617-552-1762). 